This is an electronic reprint of the original article. This reprint may differ from the original in pagination and typographic detail.

Author(s): Jalonen, Jarkko; Takala, Tuomo

Title: $\quad$ Ethical Dilemmas in Finnish Debt Collection : An Explorative Case Study

Year: $\quad 2016$

Version:

Please cite the original version:

Jalonen, J., \& Takala, T. (2016). Ethical Dilemmas in Finnish Debt Collection : An

Explorative Case Study. Turkish Journal of Business Ethics, 9(1), 25-48.

https://doi.org/10.12711/tjbe.2016.9.0011

All material supplied via JYX is protected by copyright and other intellectual property rights, and duplication or sale of all or part of any of the repository collections is not permitted, except that material may be duplicated by you for your research use or educational purposes in electronic or print form. You must obtain permission for any other use. Electronic or print copies may not be offered, whether for sale or otherwise to anyone who is not an authorised user. 
Received: August 11, 2015

\title{
Ethical Dilemmas in Finnish Debt Collection - An Explorative Case Study
}

\author{
Jarkko Jalonen $^{1}$ \\ University of Jyväskylä
}

\author{
Tuomo Takala ${ }^{2}$ \\ University of Jyväskylä
}

\begin{abstract}
It is inevitable that ethical questions arise in debt collection organizations and leadership, which is then good ground to identify whether debt collection is good or evil. Therefore we consider that a good standpoint for qualitatively explain the ethical dilemmas arising in our case study context. The article adopts a case study approach to examine Finnish Collection Agency Ltd., and applies a qualitative content analysis of interview data gathered by asking five employees to answer ten questions about how they see conflicts between their work and their own ethical thoughts. We obtained a rich description of the issues facing the debt collection business in Finland. In addition, the conceptual framework is further developed for forthcoming studies.
\end{abstract}

Keywords

Debt collection • Business ethics $\bullet$ Finland $\bullet$ Virtue ethics $\bullet$ Ethical leadership $\bullet$ Deontology $\bullet$ Ethics of emotions • Ethical dilemmas

1 Correspondence to: Jarkko Jalonen, SPT-Group Ltd Yliopistonkatu 36 A Jyväskylä KESKI-SUOMI 40100 Finland. Jyväskylä School of Business and Economics, Leadership and Management Program, FI-40014 University of Jyväskylä, Ylistö, Ohjelmakaari 10, Finland. Email: jarkko@sukanvarsi.fi

2 Jyväskylä School of Business and Economics - Leadership and Management, University of Jyväskylä, Jyväskylä, KESKISUOMI Finland. Email: tuomo.a.takala@jyu.fi

Citation: Jalonen, J., \& Takala, T. (2016). Ethical dilemmas in Finnish debt collection - An explorative case study. Turkish Journal of Business Ethics, 9, 25-48. 
Ethical questions have become more and more important in contemporary leadership discussions, and business ethics is not a separate subject from business administration (Allinson, 1998). Debt collection, in general, causes emotional responses when people talk about it, and as stated by Aristotle, the emotions are our built-in alarm system for ethical matters (Brown \& Mitchell, 2010). The debt collection business provides good grounds for seeking and understanding good and evil in business. In this case study, we investigate the impact of the ethical question of employee behavior and leadership challenges in debt collection agencies. We have identified that there exists an evident lack of this kind of research in Finland. The ethical problems in this branch of business are by nature acute, and so the research task is well motivated.

The general aim of this study is to increase our understanding of the impact of ethical questions on employee behavior, and to decide whether the debt collection industry can be seen in general as evil. More specifically, we set out to study what is good and evil in the debt collection business and how ethical questions are reflected in the internal communication and management of a debt collection agency. However, we do not attempt to generalize our findings because that would be outside the scope of this single case study.

One important reason for studying debt collection from the ethical perspective is practical gain or utility. By investigating the ethical dilemmas prevailing in the debt collection business, the owners and the management of such firms are able to find out how workable and good the mechanisms of debt collection are. It is important to resolve whether it is reasonable to motivate employees to use ethical debt collection principles, or whether the kind of morality the employees have in regard to debt collection even matters.

We assume that debt collection is generally considered problematic, or even a bad or evil branch of business (by the general public). It could be that the environment of debt collection as a business area makes its soil too toxic a working atmosphere and employees try to motivate themselves by justifying their work through their own personal moral principles; that is, values, moral habits, logic and so on.

To put it more clearly, we want to use this case study to describe and qualitatively explain what kinds of ethical dilemmas become evident among the employees of a debt collection firm and how. Through this study we will observe one Finnish debt collection firm to contribute to discussions on moral dilemmas, the principles of good and bad actions, and leadership. We will consider the legal point of view, but more profoundly we will use ethical concepts and theories. This means that we will explore whether some kind of continuum exists from "wrong-doing" to "evilness" in the beliefs and thoughts of the employees studied. In addition, deontology and virtues will be explored in connection with the principles of debt collection. 
So by these means we hope to obtain a clear picture of the details of conducting a debt collection service in one Finnish firm. The sample is quite small, but we believe that by using several in-depth qualitative essay-interviews, the purpose of an explorative case study can be achieved. We hope that the results of this study can serve as the basis for further larger studies of debt collection in the context of ethical dilemmas in national and international contexts.

\section{The Debt Collection Service Industry in Finland}

The debt collection service industry is a service field where debt collection agents collect their clients' receivables from debtors where the receivable is overdue and the debtor has not paid the principal amount according to the terms the creditor and debtor previously agreed. In Finland, the debt collection service industry contains 135 companies (List of Debt Collection Companies, 2014). Debt collection is often not the only business these agencies are engaged in. In general debt collection is not only limited to debt collection agencies; therefore, many times debts are collected by the creditors' own actions. In addition, governments also collect debts in the form of collecting unpaid taxes. This study aims to understand debt collection conducted by debt collection agencies.

There are many regulations and laws to follow in debt collection in Finland, and every debt collection agency needs a license to operate from the Regional State Administrative Agency. The Regional State Administrative Agency monitors and controls all debt collection agencies in Finland and the debt collection agencies are obligated to report annually to this authority.

The most important legislation in the field is the DebtCollection Act(22.4.1994/513). This act describes how debt collection should be carried out before resorting to legal action such as issuing a court summons. The strictest provisions included in this act cover consumer debts. A consumer debt is a debt, where the debtor is an individual and the creditor is some business or related entity. A consumer debt is also based on goods or services meant for consumption by private individuals.

Debt collection is also controlled and monitored by the ombudsman. The ombudsman delivers rulings on particular situations or conciliates over conflicts in consumer matters. The ombudsman's rulings are not enforceable, but the courts and other authorities mostly form their own rulings on the basis of the ombudsman's ruling; therefore, these function as de facto regulations. That is why debt collection agencies follow the ombudsman's rulings. The ombudsman also publishes documentation about what is good practice in the field of debt collection and the Debt Collection Act obliges debt collection agencies to follow these guidelines. 
If the debt collection agency or the creditor themselves cannot make the debtor pay the debt willingly, the creditor will commence a court procedure by issuing a summons. In the basic debt collection process, the court will hand down a judgement by default. The court process for that is not a full-scale court procedure - it is what is referred to as an expedited procedure. This procedure involves the bailiff issuing a summons to the respondent (debtor) requesting him or her to answer to the demands, and if there is no answer, the court makes a ruling without hearing the debtor. This expedited procedure in the courts is mostly handled by notaries rather than judges.

The court is also obliged to interfere in matters that are clearly a breach of the law, even though the respondent does not point them out. These checks are mostly carried out by notaries, who sometimes apply new interpretations of the law. Sometimes these interpretations are clearly different from how the legislation has been applied in the past. However, they remain in force because the debt collection agencies, which collect sizeable debts, do not start questioning such negligible matters. Sometimes notaries even call or contact the debt collection agencies and start to give instructions on how the debt collection agency should apply certain laws - these instructions are sometimes contrary to the general interpretation of the legislation. The employee in the debt collection agency copes with all this, although it might raise some ethical issues in terms of whether he or she is actually doing the right thing. The court is seen as an authority, the rulings of which should not be questioned.

The judgment in force could be sent to the enforcement authorities for the enforcement procedure. The debt collection agency employee sees the documents about the enforcement procedure and how the authorities sell the debtor's property to fulfil his or her obligations, which might raise ethical considerations.

Discussion and debate in parliament forms the basis for new laws. The issue of quick loans, which in the media and public discussions have been seen as a bad thing in society, has recently been raised in the Finnish parliament. In these discussions, the companies providing the quick loans are seen to be connected to debt collection agencies. These discussions resulted in changing the debt collection act and a new debt collection act came into force on 16 May 2013. This new act has some provisions especially for quick loan companies, which reduces their profitability. These new provisions also effected ordinary debt collection, and cast a shadow over the debt collection service industry.

On the other hand, the media presents debt collection agencies as greedy, and in public discussion, debt collection agencies are also connected in extreme cases to outlawed motor bike clubs or other kinds of threats. 
The employee in the debt collection agency is in the middle of this environment and is often associated with the parties described here. Many consider that the debt collection agency is greedy, bad or even evil. How can this employee justify his or her actions as a debt collection agent?

\section{Theoretical Background}

Studies around ethical dilemmas. In the literature on moral dilemmas, it is common to draw distinctions between the various types of moral dilemmas. It is possible to distinguish between two different kinds of moral certitude: certitude in regard to the final conclusion about what should be done, and certitude in regard to the conflict of values that is the source of the dilemma. The moral dilemmas with which our paper is concerned are of the second kind; where one generally understands the values or the principals involved, but does not know how to resolve the empirical conflict. In epistemological terms, a moral or ethical dilemma is a situation in which the person does not know how to act because of conflicting beliefs about what is required (see also Lurie \& Albin, 2007).

We conducted a wide search for literature on ethical dilemmas, concepts of ethics and ethical leadership within the debt collection industry environment but we found only the following studies, which also describe the theoretical background for our paper. Generally, we could state that ethical theories pertaining to the debt collection industry are not widely researched.

The debate surrounding ethical dilemmas in general is one of the most important. Warren (2011) found that the ethical dilemmas of ship owners concerning piracy off the coast of Somalia are avoided through cooperative efforts between ship owners and nation states. He used the virtue ethics perspective to consider ethical issues. In the Finnish context, Takala and Uusitalo (1995) studied the professional ethical dilemmas faced by retailers. They found four themes to be useful in the analysis: freedom versus rules, principles versus moralizing, boundaries versus transition, economy and morality versus subjective judgement. They used a multi-part moral theory approach consisting of duty ethics, virtue ethics and utilitarianism. Larkin's (2000) study surveys the internal audit department of a large financial services organization, in which respondents were challenged to recognize and evaluate ethical and unethical situations often encountered in practice. Four key demographic variables were investigated: gender, age, years of employment and peer group influence. For the most part, the respondents view themselves as more ethical than their peers. There does appear to be a gender effect suggesting that women have the ability to identify ethical behavior better than their male counterparts. 
A study by Trapp (2011) noticed that companies often utilize several forms of mostly one-way communication such as codes of conduct. The extent to which these efforts, in addition to information about the company stance on ethics, are able to positively influence behavior is disputed. In contrast, research on business ethics communication and behavior indicates a relatively clear positive link between open workplace dialogue on ethical issues and ethical conduct. In his article, Trapp therefore addresses the question: What influences employee attitudes about talking openly about ethical issues? Answers are proposed on the basis of focus group interviews with staff at the Danish and Brazilian affiliates of the global healthcare company Novo Nordisk. It was found that interest in discussing ethical issues was influenced by two main factors: employee conceptualizations of business ethics and the level of inter-collegial trust, credibility and confidence.

The case study by Van Cranenburgh and Arenas (2013) illustrates the dilemmas facing multinational companies in meeting social challenges (especially healthrelated) in Sub-Saharan Africa. From a business standpoint, social challenges in developing countries differ greatly from those in nations where governments or markets effectively provide for the population's health needs. The case illustrates what led a multinational to set up a corporate foundation, and focuses on three strategic and operational dilemmas it ran up against. The case discussion shows that the ethical issues intertwined with these dilemmas are best understood using a variety of ethical approaches. Ethics of Care are just as relevant to analyzing corporate social responsibility and corporate philanthropy as the deontological and utilitarian theories commonly used in business ethics. From our point of view this study put forth elements that come close to the discipline of Management by Mercy.

We agree with Tomperi (2014, p. 36), when she shows an interesting angle on the current state of ethical leadership in Finland provided by Huhtala et al. (2011b), who have studied the relationship between the ethical dilemmas Finnish managers have and the ethical strain and stress they experience. Their research showed that a quarter of the 902 managers surveyed found ethically challenging situations stressful, and that the stress was linked with exhaustion and burn-out at work. Huhtala et al. also found that the most typical ethically challenging situations were related to the availability and use of resources.

Good in its many contexts. What does "good" really mean? We could find several meanings for good. For example, G. H. von Wright, in his book "The Varieties of Goodness" (2001), includes the following terms, concepts, and phenomena:

- Instrumental good;

- Absolute value good; 
- Technical good;

- Virtuous good.

Even though von Wright uses the term conceptual approach in reference to his philosophy (i.e. deontic logic), he often uses examples and real world observations to argue his reasoning. Therefore, the empirical world enters philosophy as if through the backdoor.

From our point of view, "goods" that are connected with utilitarianism, deontology (Kantianism) and virtue are central, and we expect to find this kind of logic of action in our case organization.

The two major traditions dominating current thinking in moral philosophy are deontology and utilitarianism. A third tradition, virtue ethics, may be useful in the context of business ethics because it applies to the controversies between general virtues and professional virtues. A fourth tradition that will be discussed here is the ethics of emotions.

Deontology. In deontological reasoning it is supposed that there are prima facie ideals which direct our thinking. Kant (1959) provided much of the reasoning that underlies modern deontology. His conclusions are based on two concepts. First, he states that the only possible basis for establishing a moral tradition is human reason or logic. The second concept is whether an action can be universalized. For example, one statement from Kant's "categorical imperative" is that "one ought never to act unless one is willing to have the maxim on which one acts to become a universal law." According to Kant, good will, and only good will, can be universalized. Therefore, exceptions to universal rules should be tested or questioned as to whether they meet the criterion of universalized good will. Modern interpretations of deontological ideals suggest that the ideals may be considered "universal" in character but not necessarily "absolute" (Ross, 1930).

Utilitarian reasoning had the most support when operators justified their actions regarding economic benefit (=instrumental good). Duty and benefit were often mixed up in people's speech. Their meaning was blurred and the lines of argument created by the operators broken. This can be interpreted in a way that supports Frankena's (see 1973) mixed deontological philosophy as a frame of reference. Deontological reasoning was used, for example, in describing the personnel management processes of a company.

Virtue ethics. is a favorable starting point for studying management and leadership ethics. All the operators studied here could name virtues for their operations, worthy of aspiring to. They also named professional practices already in use that they 
considered to be virtuous. The tradition of virtue ethics has been applied to the analysis of the ethical concerns of various professionals. All professional activities may be regarded as being guided by specific -artificial- virtues. Therefore, general moral considerations and psychological descriptions may be inaccurate when applied to professional life; for example, to the acts of such professionals as doctors, policemen and marketing staff. Many professions deal with problematic areas, and professional virtues are necessary in performing tasks effectively. Virtues can be defined as the beneficial tendencies to act; they are role-related, artificial character traits, which serve the goals of professions. It is possible to describe an ideal professional whose typical behavioral tendencies, values, and other important features are such that they serve the goals of his/her profession. Consequently, there is an evident gap between general moral considerations and professional duties and values. For certain professions this gap may be wide. In the world of professionals, professional goals are seen as good in one way or another. Professional virtues serve the goals of the profession. Although professional virtues may be different from ordinary virtues (honesty, fairness, impartiality, etc.), they are justified because of the goals they serve. Some provocative examples: business defies honesty through the practice of offering and taking bribes; advertising produces blatant lies, distorts reality and creates artificial needs to make profit for a firm. A used car salesman must be a professional liar to succeed in his business. A profession's socially justificatory argument (statement of leading goals) provides rather narrow limits for professional activities and virtues. Considering business life, a relativist might argue that it is foolish to require business people to follow the norms of honesty in any other sense but that which is internal to business life. Ruthlessness is an example of business virtue, which is not a virtue in the outside world, and the virtue of honesty must be studied from the inside point of view of business life (Takala \& Uusitalo, 1996).

Evil in its many contexts. Evil is the other side of the coin, the opposite of "good." Thoughts that are good are not evil or bad. The word "evil" has many meanings depending on the context. First, evil can be seen as synonymous with bad - it is like any situation where there is a lack of good, or where bad things are happening to human beings like death or serious illness, such as the plague. Second, evil might be seen as synonymous with wrong - as in doing a wrong thing. Third, evil might even be more than just wrong such that all wrong doers are not necessarily always evil. That is then one way to define what is evil by trying to identify the difference between what is simply a wrong thing but not evil (Formosa, 2008).

Furthermore, in the business organization, the most crucial task of resisting evilness has been put on the leaders. What is the responsibility of the individual person? Hanna Arendt (1963) states that evilness could become "banal" as in the Nazi concentration camps. Evilness could be so common in everyday life that it could 
be located in the whole administrative system. The whole system could be rotten and evil, and the individual sees himself as irresponsible and non-empowered.

Nazi commander SS Adolf Eichmann was a major operational actor in carrying out the Holocaust. Arendt concludes her analysis of Eichmann, and his organizational situation, with the judgement that Eichmann was guilty, but instead of being an insane or monstrously evil person, he was well within the range of sanity and normality. Eichmann was a thoughtless and "banal" person who did not understand what was right and wrong about his role as a manager in an organization that harmed people. He was not able to distinguish right from wrong in his organizational context because he did not think about what he was doing or who he was cooperating with (Arendt, 1963; Nielsen, 1984).

Primo Levi survived the Nazi holocaust and wrote many books about evilness. He states that to survive, one has to own almost one reason to live. "Survival in Auschwitz" (1955) is Levi's classic account of ten months he spent in the German death camp, a harrowing story of systematic cruelty and miraculous endurance. Remarkable for its simplicity, restraint and compassion, this book remains a lasting testament to the indestructibility of the human spirit and a prayer for individual responsibility.

Zygmunt Bauman states that evilness, the Holocaust as its ideal-type, should be seen as deeply connected to modernity and its order-making efforts. Procedural rationality, the division of labor into smaller and smaller tasks, the taxonomic categorization of different species, and the tendency to view rule-following as morally good, all played their role in the Holocaust coming to pass. He also argued that for this reason modern societies have not fully taken on board the lessons of the Holocaust and its evilness (2001).

Group pressure and individual responsibility are problematic issues. Both naturalistic observations and experimental studies support the idea that ordinary human beings are ready to engage in violent acts when severe group discipline is exerted or as members of vicious sub-cults (Rogers, Stenner, Gleeson, \& Rogers, 1995). As shown in many social-psychological field studies, the common man is ready to give electric shocks and beatings to his fellows if strong leaders give the orders to execute such actions (see Huczynski \& Buchanan, 2001). But in the case of a debt collection firm, this is meant to be part of normal business, not a cult. However, we can assume that there are some features of the debt collection business, which could lead the employees of the firm to similar kinds of actions. It could be that moving from bad to evil actions happens little by little. No one wants to be an evil or corrupted person but this is a kind of process. We shall call this process moral erosion, and it is connected to lying as a moral choice. According to the study by Takala and Urpilainen (1999) on managerial work and lying, to leave things unsaid is not considered lying. It could be said in general that lying is about misleading 
someone about some truth - that then means there exists some kind of truth. We should then consider whether truth is absolute or subjective.

Ethics and emotions. There are several lines for studying ethics and emotions in philosophy. In classical ethics, for example, in Kantianism or Aristotelism, the role of emotions is seen as being harmful, and disturbs the thinking of the rational human (white) man. Nowadays, more up to date ethical streams are popping up that are more positive concerning emotional actions in ethical decision-making. We found the following stands as interesting perspectives:

Emotivism. The development of emotive theory in this century is based largely on the work of Stevenson (1944). The theory consists of the following contentions:

- People have attitudes that often clash.

- To have an ethical conviction or opinion is to have an attitude.

- Ethical utterances express the attitudes of the speakers, and as a result have an influence on the attitudes of the hearers.

- To support an ethical statement by "reason" is to mention a fact that will influence the corresponding attitude.

- The use of ethical sentences in self-exhortation is parallel to interpersonal persuasion: personal "reasoning" about ethics is similar to interpersonal debate.

- Ethical sentences do not state facts, although in some contexts they give information.

Therefore, the issue in a proper ethical debate is more a matter of emotion than a matter of reason. Our moral attitudes are seen as emotions, not as a reflection of moral consciousness, and so on (Brandt, 1959, p. 203).

We can also define ethics and emotions as belonging to the sphere of care ethics - as an ethic grounded in voice and relationships, in terms of the importance of everyone having a voice, being listened to carefully (in their own right and on their own terms) and heard with respect. An ethic of care directs our attention to the need for responsiveness in relationships (paying attention, listening, responding) and to the costs of losing connection with oneself or with others. Its logic is inductive, contextual, psychological, rather than deductive or mathematical (Gilligan, 2011). At the end of this paper we will provide some suggestions for better leadership in human organizations based on care ethics.

Ethical leadership. To understand the term ethical leadership, we can approach it by defining "ethics" and "leadership" separately. As we described "good" before, now we will take a look at leadership in order to combine the theories of leadership 
and ethics. In order to conduct a meaningful leadership ethics study, it is important to embed a definition of leadership within the study (Ciulla, 2004).

There are many different definitions of leadership, and an unambiguous definition has been difficult to find. Harvey (2000) presents a deeper understanding of leadership by defining what leadership is not. The essential element of a definition of leadership in the context of ethics is that there is a leader who has followers who follow the leader willingly. It is also worthwhile considering transformational leadership. Transformational leadership is described as leadership that targets deep changes (Lämsä \& Päivike, 2010). It is typical for a transformational leader to consist of idealistic impacts, inspiring motivation, intellectual stimulation and individualism - also known as the four "i"s (Sivanathan \& Fekken, 2002). Transformational leadership has a connection to ethical leadership, as James MacGregor Burns states that transformational leaders foster moral virtue (as cited in Ciulla, 2004).

According to Treviño, Hartman, and Brown (2000), ethical leadership contains two pillars -moral person and moral manager. In their descriptive approach, moral people are seen as honest, trustworthy and concerned about people via open behavior. Whereas moral managers are seen through how the leader uses the position of leadership in an ethical manner- he or she can appear for instance as a role model or alternatively may use rewards and punishments to ensure standards are followed. Ethical leadership in the approach adopted by Treviño et al. therefore describes a leader as a person who has high moral standards and uses his or her position of leadership to ensure those standards are followed.

Ciulla (2004) states that it is more important to answer the question "what is good leadership?" rather than just "what is leadership?" The good here has two senses ethical good and technical good or effectiveness. Therefore, to be a good leader one must be ethical and effective.

By combining these definitions of ethics and leadership we arrive at a definition where ethical leadership means leadership that seeks the good, and where followers follow their leader willingly.

\section{Research Method}

The research method for this study is qualitative content analysis, which is a method for systematically describing the meaning of qualitative material (Schreier, 2012). This is carried out by classifying material as instances of categories in a coding framework (Schreier, 2012). The method is based on qualitative content gathered via written essays by the employees of the case firm.

The idea of the study is to explain phenomena arising due to ethical questions and how the debt collection service industry is perceived from the debt collection agent's point of view. For this purpose qualitative interviews are a good way to gather 
the data. The first author of this paper is an entrepreneur in the Finnish Collection Agency Ltd., and so it may appear that the data for the method adopted in this study is explained and reflected upon more using the first author's own thoughts and knowledge of the background involved. However, because of the first author's own presence in the case company, the data is gathered by asking the participants to answer questions in the form of written statements instead of in a spoken interview.

\section{The Case Firm - A Presentation}

The Finnish Collection Agency Ltd. is a medium-sized debt collection agency in Finland. The largest agencies in Finland have more than 100 employees, and there are over 100 small agencies with less than five employees each. The Finnish Collection Agency Ltd. at the time of this study had approximately 20 employees, and in terms of annual turnover, it is Finland's eighteenth largest debt collection agency (there are in total 140 debt collection agencies in Finland).

The Finnish Collection Agency Ltd. was founded in 2008 in the middle of the economic recession, and the company quickly established a position in the market by introducing an easy-to-use debt collection service with minimal risk to its customers. Rapid growth started in 2009 and continued with annual turnover growth of more than 50\% until 2012, when the company started to stabilize. In 2013, the Finnish Collection Agency Ltd. had an annual turnover of 1.3 million euros.

The Finnish Collection Agency Ltd. has been profitable every year but profits have only been around $6 \%$ on average, which is mostly because of the rapid growth, which is funded only by the profits from the last few years.

At the beginning of 2014, the Finnish Collection Agency Ltd. started to expand outside of Finland's borders, and in March 2014 its Tallinn office was founded. The trademark SPT was also registered as an international brand when the company planned to dedicate more energy to its international debt collection business.

\section{Data Collection}

All of the employees in the Finnish Collection Agency Ltd. were asked to take part in the study if they wanted to and five of them were willing to offer answers to the study questions $(N=5)$. The participants came from various positions in the organization: one in sales, two were debt collection agents, one was the human resources manager and one was the chief executive officer. The human resources manager and chief executive officer are seen as supervisors and the other three as subordinates. There were seven general questions for every participant and the last three questions were different for the supervisors and subordinates. Three of the participants were female and two male. The ages of the participants were from 25 to 37. 
Data collection began by asking the five participants to take part in a small introductory presentation where the aim of the study was described and the basic theoretical background was introduced. The presentation provided instructions on how to present their answers in the written essays on template documents on their computers. The participants were instructed that they could write their essays anytime on the data collection day and they could spend one to two hours. When the answers were ready they were instructed to send them to the first author via e-mail.

For every participant there were ten questions where they expected to answer in written essays. There was no maximum or minimum for the answers - the only instructions were that they can write anything that pops into their minds from each question. Some answers were then very short and some more mature yet every participant answered at least something for every question.

The seven general questions for every participant considered the participants tasks, which they conduct according to their own moral code and how they cope with conflicts. The questions also studied the participants changing moral opinion or what might change it. The questions considered the participants' own thoughts but also how they see the thoughts of other member in the organization. There were also questions about whether debt collection in general is good or evil.

The three special questions for the subordinates were about their attitudes towards lying. Have the subordinates ever experienced the supervisor lying? Are they forced to lie in their work and how does it affect them?

The three special questions for the supervisors were also about their attitudes to lying, but in terms of whether they lie to the subordinates or do the subordinates lie to them. The supervisors were also asked whether they see that the subordinates are conducting tasks which are against their own moral code.

The essay answers were written in the Finnish language.

\section{Findings}

The data were analyzed using content analysis by searching for connections to the theoretical background. We found several themes by sorting the data under the coding framework of the ethical theories of deontology, ethics of emotions, concept of evil and virtues. The themes were "reasoning by law," "lying," and "good or evil debt collection."

\section{Reasoning by Law}

The employees in the debt collection agency seem to change their ethical position when they discover the reason for some ethical decision from the law. For instance, participant 2 had the following answer to the question about changing his/her ethical opinion: 
Hereby I would like to include all matters for which I have legal reasoning. There still might be matters, which still make me think, but the law is the law and that must be followed. (P2)

In the debt collection service industry, employees are very often dealing with legislation, and therefore, general discussion in the workplace is about which law is applied in a particular situation and how. That mind set seems to become their way of thinking - if the law says something, it must be followed. Still, the question arises about whether the law is always ethically correct, but as we see, participant 2 ends up saying "the law is the law". The other participants provide similar ideas:

Many times if the modes of working (although in the beginning they feel morally wrong or weird) are found for instance in a law on which the matter is based - the reasoning for that matter becomes easy for me and there is no need to speculate morally anymore. "The matter is what it is and that's it" Still there are many ways to apply the law. (P3)

In response to legislation and collateral employment contracts we cannot do anything. (P5)

Individual observations from the surrounding reality changes their understanding of reality (known as a scheme), which again guides the kinds of new observations the person has (Neisser, 1982). In the debt collection service industry, employees seem to change their scheme more and more, so that what is written in the law is seen as morally correct, and there is nothing to question at all.

Responsibility is not only about following the law because the law only includes the minimum obligation, the law does not necessarily fit with one's own moral code, and responsibility should also contain the will to act in the right way without setting one's own benefit before anyone else's (Takala, 1993).

\section{Lying in a Debt Collection Agency}

Many interviewees thought that leaving something unsaid is also lying.

Is it lying, if someone left something unsaid? For instance, in a sales situation. In my opinion it is. (P1)

Something left unsaid can logically return us to the idea that there is some truth that is left unrevealed to someone who has the right to know. The significant background to lying is then that truth does exist. In scientific philosophy there can be truth based on rational and logical thinking (rationalism), or truth can be something built into relations between human beings (constructionism). This study is about the individuals in organizations, which then makes the idea of truth that is constructed in relationships more relevant. In constructionism, the idea of truth makes us ask whose truth is it then. What is truth for one may not necessarily be for another. 
The first author of this paper also knows that when the research data was being gathered, it was a busy and stressful time for all the employees. Grover and Hui (2005) have highlighted in their study that work pressure increases lies. Grove et al. also found that if one benefits from lying, this increases the probability of lies.

The Debt Collection Act obliges debt collection agencies to have a strong privacy policy, which means for instance that parties in a debt collection assignment cannot be revealed to a third party. Sometimes a third party makes inquiries to a debt collection agency about an assignment - for instance, sometimes the parents of a young debtor ask about their offspring's debts. The Debt Collection Act prevents the debt collection agencies from revealing anything in that situation. If the participants see that something left unsaid is lying, the participants may see that part of the Act has forced people to lie - the legislation or the debt collection agency's policies prevent them from saying something, which is therefore the same as lying. This improves our understanding of lying - that maybe it is not lying when someone does not have the right to know something, and it is left unsaid because of that. Yet forced lying is seen to exist:

Lying is always sad, especially if it is "forced" to occur according to your job description. (P3)

Kant's principle of a universal law, where some matters should always be left undone, if it cannot be done according to universal law (Korsgaard, 1986). According to Kant, we can also consider that the debt collection agent should respect his/her moral code (conscience) and not seek norms from society through such elements as legislation. Here we see that the debt collection agent's moral code (conscience) is sometimes in contradiction with legislation. Being forced to lie affects ethical conflict in the participants:

This matter connected to "forced lying" affects my work and comfort somehow, but not significantly. (P2)

There is lying in the organization that is targeted at instances outside the organization but also inside the organization. The study data reveals that lying exists between leaders and subordinates. It is also highly probable that there exists lying between all the members of the organization, but that it is not so significant, as the study data did not reveal any such instances.

The following answer clearly describes such internal lying:

Is it lying to leave something unsaid? I don't want to lie, but in some circumstances I've left some detail unsaid. Some of these are related to unclear situations for which there are many ways to solve them and the final solution is still under examination and that is not yet public information. In some situations there was the need to end up at some decided objective. I have also left some things unsaid because they could be seen as threatening for the employees, if the atmosphere has not been so good for sharing that thing. (P5) 
In many answers the subordinates thought that the leaders are forced to lie because of instructions from the senior management:

Yes, sometimes the superiors lie. In my opinion it seems that the leaders together have decided some rules/instructions and none of the superiors can make exceptions to those even if their own opinion might be different to those. (P2)

Superiors lie in some situations. I've noticed that a superior sometimes has a different opinion, but he/she still wants to follow the senior management's instructions and that's why he/she lies to the subordinates in order to make the subordinate share the same opinion. (P1)

However, the answers from the superiors did not indicate that they were forced to follow some instructions to lie, but the leaders described their lying more that there was still something so unclear for them that it was better to leave it unsaid because those matters are still incomplete. Anyway that experience of lying is perceived to reduce trust and comfort:

The following reduces my trust in superiors and reduces my comfort in the company. (P2)

About building trust in the organization, Paul Glen (2014) highlights this clearly in his study in regard to the problem of building trust: "We do not trust them because they don't trust us."

\section{Good or Evil Debt Collection}

The first author's sentiments as an entrepreneur in the debt collection service industry are described well in participant 5 's comment:

My own reputation has been affected from working in the debt collection service industry, for instance, I no longer say where I work in the first place. I'm tired of hearing base jokes about motorbike clubs and loan sharks when it is time to relax. (P5)

It seems that working in the debt collection industry can be characterized according to this comment from participant 5. People really do react with comments about motorbike clubs and so on when they learn where an employee works.

The debt collection agencies are also seen as disgusting and operating outside the law:

In Finland debt collection agencies are perceived as a disgusting and law breaking industry in one sense. This might be because many associate us with the fast loan companies. (P1)

This observation connected to the idea of the organizational mind-set of legislationbased reasoning is interesting. On the other hand, the culture inside the organization is strictly related to the law, and at the same time, the employee sees that society thinks that debt collection agencies operate outside the law. 
Working in a debt collection agency is not in the list of dream jobs:

...it is not a dream job [working in a debt collection agency] at all, as I have heard from people's discussion. (P2)

On the other hand, the first author has heard people equate working in a debt collection agency with working as a dustman. According to research in the USA by CareerBuilder.com (Institute of Management \& Administration, 2007), the most important features for a dream job are having fun at work (39\%) and that the work changes something in society (17\%). They showed that $20 \%$ of their participants had a dream job. It is possible to think of working in a debt collection agency as having an effect on society, but what are the effects and are they seen as morally good or evil?

On the other hand, we could ask the question in this context that if morality is about seeking good, what is evil then? Evil has been seen in many ways - evil itself and doing wrong. But all wrong doing is not necessarily evil (Formosa, 2008). Further research about jobs could examine those that are seen as evil and ask the employees whether they see their work as evil or only as doing the wrong thing.

Working in a debt collection agency is simply doing everything necessary to achieve a situation where a debtor pays their unpaid debt. That might be the root of the evil in the debt collection service industry. Tang and Chiu (2003) studied a sentence from the Bible and asked whether the love of money is the root of all evil. According to their study, low satisfaction with one's own income increases unethical behavior. Even though that study was made in Hong Kong, it also illustrates the connection between money and evil in this study. The debtors the employees in the debt collection agency have to cope with tend to be experiencing money problems, and therefore, they are not satisfied with their income and that makes them behave unethically, which might result in them seeing the debt collection agency as a source of evil.

\section{The Impact of Ethical Questions on the Debt Collection Agency}

Pacta sunt servanta -in legal terms is the common sense that what is agreed should be followed. The agencies in the debt collection service industry and their employees are dealing with the dark side of that rule-someone has failed to follow the provisions of an agreement and have left something unpaid. Here we consider this rule from the point of view of deontology, ethics of emotions, the concept of evil and virtues. In the following table, we will present ideas concerning ethical concepts in the context of the study. 


\begin{tabular}{|c|c|c|c|}
\hline \multicolumn{4}{|c|}{$\begin{array}{l}\text { Table } 1 \\
\text { Ethical Issues and Empirical Findings of the Study }\end{array}$} \\
\hline Perspective & In debt collection & Research question & Study findings \\
\hline Deontology & $\begin{array}{l}\text { It is universal that one } \\
\text { should follow the rules } \\
\text { one has agreed. / It is } \\
\text { one's duty to follow the } \\
\text { rules agreed. }\end{array}$ & $\begin{array}{l}\text { What can be considered } \\
\text { the common rules of the } \\
\text { debt collection industry? }\end{array}$ & $\begin{array}{l}\text { The debt collection agent should respect } \\
\text { his/her moral code (conscience) and not } \\
\text { seek norms from surrounding society } \\
\text { such as legislation. Only actions in } \\
\text { respect to a moral code are considered } \\
\text { right and dignified. The moral code is } \\
\text { different to society's legislation. }\end{array}$ \\
\hline $\begin{array}{l}\text { Ethics of } \\
\text { emotions }\end{array}$ & $\begin{array}{l}\text { Debt collection causes } \\
\text { emotions and those } \\
\text { should not be excluded } \\
\text { from ethical analysis. }\end{array}$ & $\begin{array}{l}\text { What effect do emotions } \\
\text { have in the practical } \\
\text { ethos of the debt } \\
\text { collection agent and their } \\
\text { professional ethics? }\end{array}$ & $\begin{array}{l}\text { The debt collection agent should avoid } \\
\text { illegal, violent and inappropriate methods } \\
\text { in his/her work. The debt collection agent } \\
\text { should control his/her impulses. }\end{array}$ \\
\hline $\begin{array}{l}\text { Concept of } \\
\text { evil }\end{array}$ & $\begin{array}{l}\text { When an act is not only } \\
\text { merely wrong but can even } \\
\text { be considered an evil act } \\
\text { - the difference between } \\
\text { mere wrong-doing and evil } \\
\text { in debt collection. }\end{array}$ & $\begin{array}{l}\text { What are the actions } \\
\text { one could commit in } \\
\text { debt collection that will } \\
\text { receive the strongest } \\
\text { condemnation? }\end{array}$ & $\begin{array}{l}\text { Debtor takes a debt without the intention } \\
\text { to pay it at all. } \\
\text { Illegal debt collection methods such as } \\
\text { violence - all kinds of motorbike gangs } \\
\text { collecting debts. }\end{array}$ \\
\hline $\begin{array}{l}\text { Virtue } \\
\text { ethics }\end{array}$ & $\begin{array}{l}\text { Order to decide is a right } \\
\text { or wrong act and one } \\
\text { should follow the virtues } \\
\text { of a debt collection agent. }\end{array}$ & $\begin{array}{l}\text { What then are the virtues } \\
\text { of a debt collection agent? }\end{array}$ & $\begin{array}{l}\text { Self-discipline, Assertiveness, } \\
\text { Judicial prudence, Justice, Obedience, } \\
\text { Truthfulness. }\end{array}$ \\
\hline
\end{tabular}

According to Kant (1959), one should not act unless the action satisfies a universal law - in debt collection that means one should follow the rules agreed and so pay in time. It can be considered a universal law that the rules should be followed. Of course, we could evaluate different situations, such as when the debtor has not left anything unpaid intentionally, and even the situation where the debtor is forced to leave a contract unfulfilled. In order to reveal the ethical questions in the debt collection industry, we consider the reality here of the universal law to follow the rules and pay in time.

As universal law is considered to be following the rules and following the rules means paying in time, from a deontological point of view debt collection agents should think in terms of their moral code and justify their actions by seeking answers from their conscience - not from legislation. Condemnations made under a moral code can be considered right and dignified.

The research data shows that debt collection causes many emotions and these cannot be excluded from an ethical analysis. Emotions can be seen in the debt collection industry in two ways - first, general emotions such as how a person is feeling when he or she is conducting some action; and second, professional emotions such as dealing with emotions at work like those arising in conversations between parties in debt collection cases (creditors and debtors). We can also consider that those professional emotions are like those that are more acceptable to show in the organization. General emotions might be those that one would not reveal to others, 
but one feels them all the same. The research data shows that the general emotions and professional emotions of debt collection agents are sometimes in conflict.

The debt collection agent should follow a level of self-control to avoid illegal, violent and inappropriate actions. According to Aristotle, emotions are our built-in alarm system for ethical matters (see Brown \& Mitchel, 2010), which then means that debt collection agents should listen to their emotions when making decisions about their conduct. This involves the continuous practice of self-discipline, which can also be seen as a virtue for a debt collection agent.

We can consider that some actions are wrong or bad, but which actions are so wrong that we can consider them evil? Wrong-doing and evil are separate concepts. According to Formosa (2008), evil is wrong doing which results in the strongest condemnation. In debt collection in general, for instance, this might be when a debtor incurs a debt without any intention of paying it back. For the debt collection agent, an evil action could be collecting the debt using violent or inappropriate actions. In fact, as the research data shows, debt collection agents are not willing to talk about their work when meeting new people, as they often start receiving comments about motorbike gangs and other harmful implications; this can be seen as the common opinion about the evil inherent in debt collection, when debt collection is connected with violent actions against debtors.

There appear to be several virtues for debt collection agents according to the research data, which are assertiveness, judicial prudence, justice, obedience and truthfulness. As we pointed out before, violent actions on the part of debt collection agents can be considered the evil actions those agents are used to avoiding in their professional behavior by practicing discipline or self-discipline. We assume then that self-discipline is one of the most important and descriptive virtues for debt collection agents.

\section{Discussion}

Debt collection agents in their professional work are expected to be in control of or even disciplined by their emotions, and they should avoid violent and harmful debt collection actions. Yet sometimes debt collection agents see the actions they should take as bad or evil but they reason their actions according to the law using the legislation as a kind of shield against their own ethical considerations, which is connected to our idea of moral erosion. As has been noted that moral erosion can occur when a strong leader gives orders, we can see a similar phenomenon in the debt collection context where the law takes the place of the strong leader.

The study shows that debt collection agents perceive that the general public has an aggressive image of them, which appears in common jokes about the profession. This 
aggressive image can be seen as a perception of evilness in debt collection agents. The leader of the debt collection company should then create a peaceful environment, which helps his or her subordinates resist. The leader should show mercy in all of his or her actions and beliefs with all people. These are common attributes of servant leadership (Parris \& Peachey, 2012).

In this contradictory context we suggest that the leader must care more for people. Miller (2009) in her study found that leaders who are perceived as having a personal relational basis of 'empathy with action' were also perceived as being proficient in the task of leading the organization. The role of leader as mentor and coach has become increasingly prominent because of the increased complexity within the workplace. Care-ethics may pave the way to better business practices (Miller, 2009), where care comes close to the idea of mercy.

We assert that "Management by Mercy" could be a new Christian-based leadership doctrine. This approach says that we must take care of our fellows in our work communities, and offer them mercy as often as possible. This is our duty as human beings, as Immanuel Kant also states (see Kylliäinen, 2009). This "Mercy" doctrine will offer fresh procedures in the future. Mercy is also seen as an attribute of servant leadership (Parris \& Peachey, 2013).

As our study shows, the virtue of self-discipline exists for the debt collection profession. In order to achieve a certain level of self-discipline, the employee needs support. Support can be provided by the leader's understanding of the emotions and ethical opinions of his subordinates, and by reasoning what practices are appropriate in a given situation.

Debt collection agents should follow certain rules, laws, and more deeply certain ethical rules and behavior. The debt collection agent's character could be in conflict with his or her own self-image. It can also be said that debt collection agents are expected to act and behave in a certain way, but in such a position they might behave totally differently if they did not assume they are in that role. The significance of this conflict distinguishes those who are able to be debt collection agents from those who cannot. This is an important factor in the acquisition of new personnel and appointing them to certain positions within the debt collection organization.

The debt collection industry is considered to be making a profitable business in an industry where this is increasingly difficult, while political interests want to increase control, decrease the cost of debt collection for the debtor and limit the actions available to debt collection agencies. The clock is also ticking against debt collection agencies: as each claim becomes older, the harder it is to collect the debtthe debt collection curve drops dramatically after 90 days (Giusti, 2004). That makes it more difficult for debt collection agencies to be effective, and the managers of debt collection agencies are inevitably forced to demand more from their subordinates. 
Therefore, by connecting these two ideas of care for the employees in the context of continuing high demands for effectiveness, we suggest that one good guideline for leaders in debt collection agencies would be: "Be merciful to all people but merciless about the results."

\section{References}

Allinson, R. E. (1998). Ethical values as part of the definition of business enterprise and part of the internal structure of the business organization. Journal of Business Ethics, 17, 1015-1028.

Arendt, H. (1963). Eichmann in Jerusalem - A report on the banality of evil. London, UK: Penguin Classics.

Bauman, Z. (2001). Modernity and holocaust. Ithaca, NY: Cornell University Press.

Brandt, R. (1959). Ethical theory. Englewood Cliffs, NJ: Prentice Hall.

Brown, M. E., \& Mitchell, M. S. (2010). Ethical and unethical leadership: Exploring new avenues for future research. Business Ethics Quarterly, 20(4), 583-616.

Ciulla, J. (2004). Ethics at the heart of leadership (2nd ed.). Westport, CT: Praeger Publishers.

Formosa, P. (2008). A conception of evil. The Journal of Value Inquiry, 42, 217-239.

Frankena, W. (1973). Ethics. Englewood Cliffs, NJ: Prentice-Hall.

Gilligan, C. (2011). Interview with Carol Gilligan. Retrieved from http://ethicsofcare.org/ interviews/carol-gilligan/

Giusti, M. (2004, May 17). Debt collection companies advise business owners about recovering unpaid accounts. New Orleans City Business, 1. Retrieved from http://search. proquest.com/docview/209570156? accountid $=11774$

Glen, P. (2014, April 7). The benefits of an unstructured career. Computerworld. Retrieved from http:/www.computerworld.com/article/2489176/it-management/paul-glen--the-benefits-of-an-unstructured-career.html

Grover, S. L., \& Hui, C. (2005). How job pressures and rewards affect lying behaviour. The International Journal of Conflict Management, 16(3), 287-300.

Harvey, M. (2000). Toward a definition of leadership. Financial Services Advisor, 143(3), 35.

Huczynski, A., \& Buchanan, D. (2001). Organizational behaviour. Introductory text. New York, NY: Prentice Hall.

Institute of Management \& Administration. (2007). Profile of a dream job-money comes third (IOMA's Report on Salary Surveys).

Kant, I. (1959). Foundations of metaphysics of morals. New York, NY: Bobbs-Merrill.

Korsgaard, C. M. (1986). The right to lie: Kant on dealing with evil. Philosophy \& Public Affairs, 15(4), 325-349.

Kylliäinen, A. (2009). Mercy in working life. Helsingissä, Finland: Otava Publishing.

Lämsä, A.-M., \& Päivike, T. (2010). Organisaatiokäyttäytymisen perusteet [Basics of organizational behaviour]. Helsinki, Finland: Edita Prima.

Larkin, J. (2000). The ability of internal auditors to identify ethical dilemmas. Journal of Business Ethics, 23, 401-409.

Levi, P. (1955). Survival in Auschwitz. New York, NY: Touchstone. 
Lurie, Y., \& Albin, B. (2007). Moral dilemmas in business ethics: From decision procedures to edifying perspectives. Journal of Business Ethics, 71, 195-207.

Miller, M. (2009). Transformational leadership behaviours and empathy with action. An International Journal of Holistic Mission Studies, 26(1), 45-59. http://dx.doi. org/10.1177/0265378809102176

Neisser, U. (1982). Kognitio ja todellisuus [Cognition and reality]. Espoo, Finland: Weilin+Göös.

Nielsen, R. (1984). Toward action philosophy for managers based on Arendt and Tillich. Journal of Business Ethics, 3, 153-161.

Parris, D. L., \& Peachey, J. W. (2013). A systematic literature review of servant leadership theory in organizational contexts. Journal of Business Ethics, 113(3), 377-393.

Rogers, R. S., Stenner, P., Gleeson, K., \& Rogers, W. S. (1995). Social psychology: A critical agenda. Cambridge, UK: Polity Press.

Ross, D. W. (1930). The right and the good. Oxford, UK: Oxford University Press.

Schreier, M. (2012). Qualitative content analysis in practice. Thousand Oaks, CA: Sage.

Sivanathan, N., \& Fekken, G. C. (2002). Emotional intelligence, moral reasoning and transformational leadership. Leadership \& Organization Development Journal, 23(4), 198-204. http://dx.doi.org/10.1108/01437730210429061

Stevenson, C. L. (1944). Ethics and language. New Haven, CT: Yale University Press.

Takala, T. (1993). Yritysetiikka ja yrityksen yhteiskunnallinen vastuu - Historiallinen tausta ja käsitteellistä pohdintaa [Business ethics and social responsibility of the firm] (Publications No 89/93). University of Jyväskylä, Deptartment of Economics and Management.

Takala, T., \& Urpilainen, J. (1999). Managerial work and lying: A conceptual framework and an explorative case study. Journal of Business Ethics, 20, 181-195.

Takala, T., \& Uusitalo, O. (1996). An alternative view of relationship marketing: A framework for ethical analysis. European Journal of Marketing, 30(2), 45-60.

Tang, T. L., \& Chiu, R. K. (2003). Income, money ethics, pay satisfaction, commitment, and unethical behavior: Is the love of money the root of evil for Hong Kong employees? Journal of Business Ethics, 46, 13-30.

Tomperi, H. (2014). Ethical team leadership as construed by Finnish managers. Retrieved from https://jyx.jyu.fi/dspace/bitstream/handle/123456789/44911/978-951-39-5972-2_vaitos 12122014.pdf? sequence $=1$

Trapp, N. L. (2011). Staff attitudes to talking openly about ethical dilemmas: The role of business ethics conceptions and trust. Journal of Business Ethics, 103, 543-552.

Treviño, L. K., Hartman, L. P., \& Brown, M. (2000). Moral person and moral manager: How executives develop a reputation for ethical leadership. Californian Management Review, 42(4), 128-142.

Van Cranenburg, K., \& Arenas, D. (2013). Strategic and moral dilemmas of corporate philanthropy in developing countries: Heineken in Sub-Saharan Africa. Journal of Business Ethics, 46, 13-30.

Von Wright, G. H. (2001). Varieties of goodness. London, UK: Routledge.

Warren, R. C. (2011). Piracy and shipowners' ethical dilemmas. Society and Business Review, $6(1), 49-60$. 


\section{Appendix}

\section{Kyselylomake - VERSIO A:}

Koetko, että jotkut muut työntekijät työyhteisössä toimivat heidän itsensä mielestään eettisesti väärin jossain työtehtävässä tai työvaiheessa? Missä tehtävässä ja miten se mielestäsi vaikuttaa heidän työskentelyynsä? (Älä mainitse henkilöiden nimiä)

Valehtelevatko esimiehet sinun mielestäsi? Miten käsityksesi tästä vaikuttaa työskentelyysi ja viihtyvyyteesi?

Oletko mielestäsi pakotettu valehtelemaan työtehtäviisi liittyvissä asioissa jollekulle (mikä tahansa taho - työkaveri, velallinen, toimeksiantaja, käräjäoikeus...)? Miten käsityksesi tästä vaikuttaa työskentelyysi ja viihtyvyyteesi?

\section{Kyselylomake - VERSIO E:}

Koetko, että alainen (ei välttämättä oma alaisesi - kuka tahansa alainen) toimii hänen itsensä mielestään eettisesti väärin jossain työtehtävässä tai työvaiheessa? Missä työtehtävissä ja miten se mielestäsi vaikuttaa alaisen työskentelyyn? (Älä mainitse henkilöiden nimiä)

Valehteletko mielestäsi alaisillesi? Mitä arvelet alaisten (ei välttämättä oma alaisesi kuka tahansa alainen) ajattelevan sinusta - eli valehteletko heidän mielestään?

Valehtelevatko alaiset mielestäsi (ei välttämättä oma alainen - kuka tahansa alainen) esimiehille? 


\section{Kyselylomake - VERSIO Y:}

Mitkä työtehtäväsi tai työtehtäviesi työvaiheet ovat sellaisia, joissa mielestäsi toimit omien eettisten ohjeittesi mukaan väärin ja miten tällainen vaikuttaa omaan työskentelyysi?

Entä mitkä ovat mielestäsi sellaisia työtehtäviä, joissa perustelet itsellesi jollain tavalla toimintasi ja millaisia nämä perustelut ovat? Koetko perustelusi jälkeen toimivasi oikein tai väärin?

Mitä sinun mielestäsi edellä mainituille työtehtäville pitäisi tehdä, että kokemuksesi vaihtuisi?

Ikuinen taistelu hyvästä ja pahasta: onko perintätoimiston työ mielestäsi hyvää vai pahaa? Entä onko se yleisesti Suomessa mielletty hyväksi vai pahaksi? Miten käsityksesi tässä vaikuttaa työskentelyysi?

Millaisia eettisiä kysymyksiä havaitset työpaikalla, missä eri henkilöillä on näkemyseroja? Miten nämä näkemyserot vaikuttavat mielestäsi työssä viihtymiseen?

Oletko havainnut tulkinta tai näkemyseroja joissain eettisissä kysymyksissä ja sen jälkeen huomannut, että näkemysero olisi kadonnut - jos näin, niin mikä mielestäsi on johtanut siihen, että näkemysero on poistunut? Tai toisaalta mikä mielestäsi voisi johtaa siihen, että näkemysero poistuisi?

Toimitko mielestäsi työtehtävissäsi omien eettisten ohjeittesi vastaisesti? Jos näin, niin millaisissa työtehtävissä ja miten se vaikuttaa työskentelyysi? 